Turkish Online Journal of Qualitative Inquiry (TOJQI)

Volume 11, Issue 1, January 2020: 110-139

DOI: $10.17569 /$ tojqi.623493

Research Article

\title{
Out of Class Language Learning Environments and Experiences Used by Learners of Turkish as a Foreign Language ${ }^{1}$
}

\author{
Hilmi Demiral. ${ }^{2}$, Şeyma Yavuz ${ }^{3}$
}

\begin{abstract}
In this study, learning environments and experiences used by Turkish learners (learners of Turkish) as a foreign language in listening, speaking, reading and writing processes were investigated. For this reason, out of class language learning environments and experiences used by 98 foreign students who completed their Turkish education in Eskişehir Osmangazi University Turkish Teaching, Application and Research Center (ESOGÜ TÖMER) were described with respect to the variable of geographical location. In this study, a case study format based on the qualitative research approach is used. A focus group interview is used to determine the language learning environments and experiences of the learners and the data were explained through descriptive analysis. Data from the result of the descriptive analysis show that out of class language learning environments and experiences of the learners do not differ according to the variable of geographical region; it is determined that out of class language learning environments and experiences activities vary according to individual differences. It is obtained that out of class activities change according to individual differences. To improve their language skills they used TV series, movies, music, and communicating with Turks. They prefer to use social media for their writing skills. Out of the lessons, not much was done by the learners in terms of reading.
\end{abstract}

Keywords: Learning Turkish as a foreign language, out of class language learning environments and experiences, basic language skills, case study

\footnotetext{
${ }^{1}$ This study has been produced from the master's thesis titled "Out of Class Language Learning Environments and Experiences Used by Turkish Learners As A Foreign Language” in the Department of Turkish Education, Institute of Educational Sciences, Çanakkale 18 Mart University.

${ }^{2}$ Dr. Faculty Member, Eskişehir Osmangazi University, Faculty of Education, Department of Basic Education, hilmidemiral@ogu.edu.tr, https://orcid.org/0000-0001-6289-3738

${ }^{3} \mathrm{PhD}$ Student, Hacettepe University, Institute of Turkic Studies, Department of Teaching Turkish as a Foreign Language, yavuz.seyma@gmail.com, https://orcid.org/0000-0002-9060-0055
}

Received: 23.09.2019, Accepted: 25.01.2020 


\title{
Türkçeyi Yabancı Dil Olarak Öğrenenlerin Ders Dışında Kullandıkları Dil Öğrenme Ortam ve Deneyimleri
}

\begin{abstract}
ÖZ
Bu çalışmada, Türkçeyi yabancı dil olarak öğrenenlerin dinleme, konuşma, okuma, yazma süreçlerinde ders dışında kullandıkları öğrenme ortam ve deneyimleri araştırılmıştır. Bunun için Eskişehir Osmangazi Üniversitesi Türkçe Öğretim ve Uygulama Merkezi’nde (ESOGÜ TÖMER) Türkçe öğrenimini tamamlayan 98 yabancı uyruklu öğrenicinin Türkçe öğrenirken kullandıkları ders dışı dil öğrenme ortam ve deneyimleri dinleme, konuşma, okuma, yazma ve coğrafi değişkenler açısından betimlenmiştir. Çalışmada nitel araştırma yaklaşımına bağlı olarak durum çalışması deseni kullanılmıştır. Öğrenicilerin dil öğrenme ortam ve tecrübelerini belirlemeye dönük odak grup görüşmeleri yapılmıştır ve elde edilen veriler betimsel analiz yoluyla açıklanmıştır. Betimsel analiz yoluyla elde edilen veriler sonucunda öğrenicilerin ders dışı dil öğrenme ortam ve deneyimlerinin dil becerilerine göre değişiklik gösterdiği, coğrafi değişkenlere göre farklılaşmadığı; ders dışı dil etkinliklerinin bireysel farklılıklara göre değiştiği tespit edilmiştir. Öğrenicilerin birbirlerinden farklı ders dışı dil öğrenme ortamları kullandıkları, dillerini geliştirmek için en çok dizi ve film izledikleri, şark1 dinledikleri, Türkleri dinleyip onlarla konuştukları; yazma becerileri için sosyal medyayı kullanmayı tercih ettikleri bulgularına ulaşılmıştır. Buna karşın ders dışında okuma öğrenimi için fazla etkinlik yapmadıkları da görülmüştür.
\end{abstract}

Anahtar Sözcükler: Türkçe'nin yabancı dil olarak öğrenimi, ders dışı dil öğrenme ortam ve deneyimleri, dil becerileri, durum çalı̧̧mast. 


\section{Introduction}

Studies related to learning and teaching mostly deal with issues related to the classroom environment. However, all kinds of activities outside the classroom also affect students' language development to a large extent. These out of class activities make a contribution to the rapid development of skills in some students and help them achieve independent learning. In order for the learners to use their language skills more effectively, out of class learning environments and experiences need to be investigated.

There has been an increase in recent studies on teaching Turkish as a foreign language and as a second language. Especially after 2000, around 140 masters and doctoral theses were made and about 100 of them were made in the last five years (YÖK, 2019). Among the studies conducted in the field of teaching Turkish to foreigners; history of teaching Turkish to foreigners (Bayraktar, 2003), principles of teaching Turkish to foreigners (Barın, 2004), problems encountered in teaching Turkish to foreigners (Er et al., 2012; Karababa, 2009) and studies on textbooks used in teaching Turkish to foreigners (Büyükikiz, 2014). However, when the publications on both Turkish teaching and Turkish teaching to foreigners are searched, it is seen that the number of thesis and articles related to extracurricular learning environments is very limited (YÖK, 2019; DergiPark, 2019).

Foreign language teaching is a multidimensional process with course books, materials and applied curriculam. In foreign language teaching, the educational dimension of the process is equally important as the way that the learner can easily use the language in daily life because language that can be used in daily life is functional. The use of materials in language classes is quite high, but these materials alone are not sufficient for language learning. The student should be able to practice the words, grammar rules and expressions learned in the classroom in daily life.

Learning the target foreign language in a country other than the country in which it is spoken makes it difficult for the language learning process. To reduce this, the learner should practice the target language as much as possible. Learning the language in the country in which it is spoken is a great advantage for learners. 
Both mother tongue teaching and foreign language teaching are structured on four basic language skills: listening, speaking, reading and writing. Just as an individual acquires listening and speaking skills in his / her mother tongue development, and then acquires reading and writing skills with the school; in foreign language learning, learners primarily use listening and speaking, which are basic language skills, and then use advanced language skills, such as reading and writing.

Undoubtedly, the basic skill that an individual gains from the first moment of his / her life and is used continuously is listening. "In sequence, a child listens before speaking, speaks before reading and reads before writing" (Lundsteen, 1971: 3). From this point of view, it can be said that the child's ability to acquire speaking, reading and writing skills and to be successful in these skills depends on listening skills. Listening and speaking have been accepted as the basis of other language skills. The listening skill plays an important role in mother tongue and foreign language learning. As cognitive activities, speaking, as a secondary skill, continues the listening process. "Aural/oral skills precede the graphic skills, such as reading and writing, as they form the circle of language learning process" (Bozorgian, 2012: 657). If an individual learns to speak by listening, if he understands something he hears or listens to, he can respond accordingly. Language is learned as it is used. According to Nan (2018:420), "Speaking without listening or listening without speaking cannot achieve the communication goal." A person who learns a foreign language, such as an individual who first listens to his / her mother tongue and then speaks, and then learns to read and write with his / her school life, tries to understand what he/she listens to in the language to which he/she is foreign. A foreign language learner who tries to find out which of the sounds heard are familiar and which are different and how to make these different sounds by trial and error, starts to read and then write with the vocabulary gained by listening and speaking skills. "Through reading, the students can enlarge their schematic knowledge which is useful for improving listening comprehension. A lot of reading enables the students to get more input by exposing themselves to various kinds of linguistic material, to broaden their knowledge, to increase background knowledge and enrich schematic knowledge, linguistic and non-linguistic. Students can enlarge their vocabulary in reading by exposing themselves to a great deal of practical and contextual words. Reading provides more opportunities for students to think about the target language. Students will be able to learn differences between their own language and culture and target language and culture. They can follow and react to different grammatical structures and idiomatic expressions quickly enough" 
(Nan, 2018:419-420). Although people don't speak as they write or don't write as they speak; According to Lundsteen (1971), writing is an expressive process transmitting language to the sense of sight. Writing skill requires logical thinking and the use of complex grammar structures. The learner, who listens and speaks from the very beginning of the language learning process, reads and then writes the information learned by these two skills, develops the ability to use the target language in an appropriate way and to express himself / herself in a logical way. With the foreign language learning process that starts with listening skills and ends with writing skills, the learner will have the opportunity to express her/his ideas in a more appropriate and correct way through these skills. The key to success in language learning is not solely dependent on teachers, a single method or a book. The success of the learner in language learning cannot be explained only by the teaching methods, the classroom environment and the teacher. In addition to these factors, the success of the learner depends on his / her own motivation, desire and language learning capacity. Language learning is not limited to classrooms. Individuals who are aware of how to learn can choose effective methods of learning a language and thus become more successful. When the literature was searched, it was seen that learning environments were not studied in the field of teaching Turkish as a foreign language. With this research, out of class learning environment and experiences used by the learners of Turkish as a foreign language will be determined. In addition, the features of language learning environments and experiences according to geographical areas will be revealed. Through this, suggestions will be made to those who will learn and teach Turkish as a foreign language regarding what kind of learning environments and experiences they can use out of class. Research is important in this respect.

Based on the contributions of the literature and study summarized above, the aim of this study is to determine the learning environment and experiences of learners of Turkish as a foreign language in terms of language skills. To achieve this goal, the following questions will be sought:

- What are the out of class environments and experiences that Turkish language learners use for listening skills?

- What are the out of class environments and experiences that Turkish language learners use for speaking skills?

- What are the out of class environments and experiences that Turkish language learners use for reading skills? 


\section{Out of Class Language Learning Environments and Experiences Used by Learners of Turkish as a Foreign Language}

- What are the out of class environments and experiences that Turkish language learners use for writing skills?

- How do the out of class environments and experiences of Turkish language learners vary according to geographical differences?

\section{Method}

In this study, where different language learning environments and experiences of Turkish language learners are used out of class, the case study design, one of the qualitative research methods, was used. "Case studies are a design of inquiry found in many fields, especially evaluation, in which the researcher develops an in-depth analysis of a case, often a program, event, activity, process, or one or more individuals" (Creswell, 2013). Learning environments and experiences that Turkish language learners use out of class and whether these environments and experiences differ according to geographical variables were investigated.

In this study, out of class learning experiences of Turkish language learners were determined using focus group interview technique. "If it is important to reach more individuals in the research and the researcher thinks that the data to be collected will be more, it is useful to conduct a focus group interview. The main purpose of the focus group interview is to understand what people think about a topic (Y1ldırım \& Şimşek, 2013). Participants in the focus group meeting cannot be expected to agree. What is important is that the participants should express their opinions and, if necessary, to discuss them. Although individual interviews are more advantageous, group interviews play an important role in revealing the opinions and ideas of the participants.

Considering that there is a sufficient number of learners related to all sub-variables such as language families, geographical area, educational status and gender in the learners of Turkish as a foreign language, it is thought that the study group can be selected among the international students studying in Eskişehir Osmangazi University Turkish Teaching, Application and Research Center (ESOGÜ TÖMER). First of all, we tried to determine the extracurricular learning experiences of 98 international students studying in ESOGÜ TÖMER while learning Turkish. Then, it was examined whether the students showed similarities and differences in terms of extracurricular learning from their previous language experiences and Turkish learning 
experiences. In addition, the learning environments and experiences that the learners use out of class while they are learning Turkish have been examined.

\section{Participants}

The research was conducted in the 2013-2014 academic year with international students studying in Eskişehir Osmangazi University TÖMER. A2 level learners who started learning late and language level B2 learners were excluded from 140 learners studying at ESOGÜ TÖMER. 108 learners remained.

As 98 of these 108 learners voluntarily agreed to participate in the interviews, the study group was composed of these learners. These learners started A1 level education in September of the 2013-2014 academic year. In the research, the whole sample was used to determine the out of class learning experiences of Turkish language learners. The interviews with the students in the study group were conducted in May 2014 when the learners were at level C1 in Turkish.

Table 1

Distribution of the Number of Learners in the Participants

\begin{tabular}{lcccccccc}
\hline & $\begin{array}{c}\text { Postgraduate } \\
(49)\end{array}$ & \multicolumn{2}{c}{$\begin{array}{c}\text { Undergraduate } \\
(42)\end{array}$} & $\begin{array}{c}\text { Private Learners } \\
(7)\end{array}$ & \\
& Female & Male & Female & Male & Female & Male & Total \\
& 3 & 4 & 8 & 3 & 1 & 1 & 20 \\
Turkic Republics & -- & 15 & 5 & 11 & -- & -- & 31 \\
Subsaharan Africa & 2 & 12 & 1 & 7 & -- & 1 & 23 \\
Arab Geographical Area & 2 & 6 & -- & 3 & -- & 2 & 13 \\
Far Eastern Geographical Area & 3 & 2 & 2 & 2 & 2 & -- & 11 \\
Europe & 10 & 39 & 16 & 26 & 3 & 4 & 98 \\
TOTAL & & & & & & &
\end{tabular}

The learners in the study group were divided into five geographical groups. Due to their languages bearing close resemblance to the Turkish language, the Turkic Republics and Afghanistan formed the first group.

20 students in this group are citizens of Azerbaijan, Turkmenistan, Kazakhstan, Kyrgyzstan, Uzbekistan, Eastern Turkestan (China), Gagauz (Moldova) and Afghanistan. In the study group, the largest group, numerically, is composed of learners from Africa. The language and 


\section{Out of Class Language Learning Environments and \\ Experiences Used by Learners of Turkish as a Foreign Language}

cultural features of the learners from Northern Africa were not included in this group because they were closely related to the Arab geographical area. 31 learners from Subsaharan Africa are citizens of Ghana, Tanzania, Somalia, Gabon, Kenya, Burkina Faso, Democratic Republic of Congo, Uganda, Malawi, Mozambique, Zambia, Cameroon, Mali and Ethiopia. The third group, Arab geographical area, also included learners from Northern Africa. 23 students in this group are citizens of Egypt, Yemen, Palestine, Iraq, Syria, Mauritania, Tunisia, Lebanon, Iran, Libya and Algeria. The fourth group comprises the learners from the Far East. 13 students in this group are citizens of Nepal, Bangladesh, India, Myanmar, China, Indonesia, Thailand and Mongolia. The fifth group comprises learners from Europe. The 11 learners in this group are citizens of Albania, Kosovo, Macedonia, Croatia, Montenegro, Latvia, Ukraine and Colombia.

\section{Instruments}

In the research, as a qualitative data collection tool, interview questions with the learners were used to determine the extracurricular environment and experiences that the learners made for learning Turkish. For this purpose, the data that the learners made during the listening, speaking, reading and writing process, through communication channels in social environments, their various ways of using language in technological environments, etc. that will reveal their experiences, were collected through a focus group interview. Focus group interview technique, which is one of the qualitative research data collection methods, helps us to understand the unobservable such as experiences, attitudes, thoughts and the individual's perspective (Y1ldırım \& Şimşek, 2013).

The aim of the focus group interview within the scope of the research is to determine the out of class language learning experiences of international learners who learn Turkish as a foreign language. Interview questions were not prepared to measure learners' knowledge; they are prepared to determine which environments and experiences they benefit from while learning Turkish.

In the focus group meeting with international learners, each interview was recorded on camera. The interview groups were planned according to the demographic features of the learners such as geographical area, education and gender. The number of learners in each group was between 6-10. The focus group interview was recorded on camera. Also, the researcher benefited from the note-taking technique. Before the interview, permission was obtained from the students for 
video recording and the interviews were completed on a voluntary basis. In the interview form prepared by the researcher, the students were asked the following questions in order to obtain qualitative data about the out of class language learning environments and experiences of the students:

1. What did you do while you were learning Turkish?

2. What kind of studies, practices and methods did you do for listening/ speaking/ reading/ writing out of class while learning Turkish?

How did you find / discover this method, practice?

- Why did you choose this method, practice?

- When / how often did you use this method, practice?

- How did you apply this method, practice?

- What are the advantages of using this method, practice?

The 970-minute data recorded on camera was monitored one by one by the researcher. These data which were separated according to the four basic language skills and geographical area variables were interpreted by content analysis.

\section{Data Collection}

In this study, in which out of class learning experiences of Turkish language learners were investigated, data were collected through focus group interview. The interviews were conducted in May 2014 with the permission of the TÖMER Directorate of Eskişehir Osmangazi University. For each interview, the students were divided into groups of 6-10 people. Before the interview, the learners were informed about the interview and the purpose of the study. Interviews were recorded on camera. A meeting room was used to make the students feel comfortable during the interviews. Learners seated at a round table were able to make face-toface contact with each other and food and drinks were placed on the tables so that they did not feel themselves in the classroom. 


\section{Data Analysis}

Qualitative data collected by video recordings during the interviews were written by the researcher without any changes. These data were then digitized with word frequency calculations. The reason for the digitization of the data is to reveal the language learning environments and experiences that the learners use the most. In order to ensure the consistency of these transcripts, 3 randomly selected video recordings and written transcripts were shown to 1 university lecturer with a Ph.D. in Turkish education, 1 student with a doctorate in Turkish education and 1 university lecturer with a doctorate in assessment and evaluation. Thus, it was examined whether the researcher showed differences with the transcripts. Following expert analysis, the basic coding differences were corrected. Systematic coding differences have been corrected in other videos.

These data were analyzed by descriptive analysis. According to Y1ldırım and Şimşek (2013: 256), descriptive analysis is summarized and interpreted according to predetermined themes. In the descriptive analysis, direct quotations are often used to reflect the views of the interviewed or observed individuals in a striking manner. In the study, while mentioning the learner comments, codes like (Iran_DR_M) and (Colombia_U_F) were made by considering the country of the learners, educational level and gender. The codes are "Doctorate=DR, Masters $=\mathrm{M}$, Undergraduate $=\mathrm{U}$, Educational cost self-financing=CSF" for educational level. For sex the codes are "Male=M, Female=F".

\section{Validity and Reliability}

For the reliability and validity study of the research data, firs of all the qualitative data collected through video recordings during the interviews were written by the researcher without any changes. These data were digitized with word frequency calculations. In order to determine the consistency of these transcripts, 3 randomly selected video recordings and their transcripts were shown to 3 experts and it was shown whether the researcher differed from the transcripts. At the end of the expert examination, the basic coding differences were corrected. Systematic coding differences were corrected in other videos. 


\section{Findings}

In this section, the findings of the environment and experiences that international learners use out of class while learning Turkish as a foreign language are presented. The findings of the research are given on the basis of listening and speaking (basic language skills) and reading and writing (advanced language skills) skills, respectively. In addition, the issues that the learners talked about during the focus group interview were given in proportion to their contribution to the research, taking into account their geographical area.

\section{Findings about out of class listening environments and experiences of Turkish language}

\section{learners}

The learning environment and experiences used by the learners to improve their listening skills while learning Turkish as a foreign language and their distribution according to geographical variables are given below (Table 2).

Table 2

Out of Class Listening Environment-Experiences and Distribution by Geographical Variables

\begin{tabular}{|c|c|c|c|c|c|c|}
\hline $\begin{array}{l}\text { Out of Class Listening Environment- } \\
\text { Experiences }\end{array}$ & 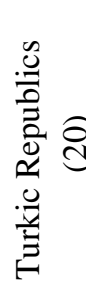 & 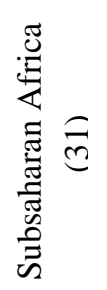 & 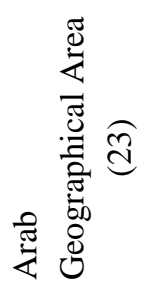 & 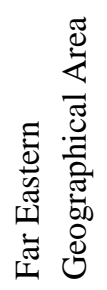 & 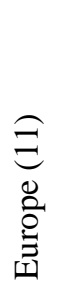 & 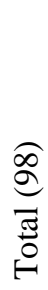 \\
\hline Watching TV series or movies & 18 & 24 & 17 & 10 & 9 & 78 \\
\hline Listening to music & 13 & 26 & 12 & 7 & 7 & 65 \\
\hline Listening to Turks talking & 8 & 14 & 6 & 7 & - & 34 \\
\hline Watching News / Documentary & 4 & 7 & 7 & 3 & 1 & 22 \\
\hline Watching television programs & 6 & 4 & 6 & 2 & 1 & 19 \\
\hline Listening to department courses & 1 & 9 & - & - & 6 & 16 \\
\hline Participation in social activities & 4 & 5 & 3 & - & 4 & 16 \\
\hline Listening to radio & - & 5 & 1 & 1 & 3 & 15 \\
\hline Watching Cartoons & 3 & 3 & 5 & 2 & 1 & 14 \\
\hline Watching football matches & - & 11 & - & 1 & - & 12 \\
\hline $\begin{array}{l}\text { Watching videos and courses from } \\
\text { phone application or on the Internet }\end{array}$ & 2 & 4 & - & - & 2 & 8 \\
\hline Listening to audiobooks & - & 2 & 2 & 1 & - & 5 \\
\hline Listening to a seminar & - & - & - & 4 & - & 4 \\
\hline Listening to poetry & - & 1 & - & 1 & - & 3 \\
\hline Listening tutorial text / religious chats & - & 1 & - & 2 & - & 3 \\
\hline Listening to roommates & - & - & - & - & 3 & 3 \\
\hline
\end{tabular}


When Table 2 is examined, it is seen that those who learn Turkish as a foreign language experience 23 different listening environments and experiences out of class. The most preferred ones are watching TV series, watching movies, listening to songs and listening to the Turks talking. Besides, it is worth noting that African learners watch football matches. In addition, African and European learners' listening to the departmental courses they will study at the university and listening to seminars by Far Eastern learners are among the out of class learning and experiences separated from other geographical groups.

"On the advice of my friends, I watched TV series and movies, listened to music every day and listened to the Turks talking." (Iraq_DR_M)

"I learned many words from the television and the Internet, and I didn't watch the news because I didn't want to have psychological problems." (Afghanistan_M_M)

"I watch the Turkish of a film which I watched in Russian. This is very useful for me.”(Uzbekistan_U_F)

"I practice the conversations of the people in the TV series, and I pay attention to where they emphasize." (Uzbekistan_U_F)

"For example, there are proverbs when watching movies. There are words used in the village. We learned this by watching movies." (Afghanistan_U_M)

"I watch the TV series two or three days a week, at first I did not understand much, then I began to understand 60\%,80\%." (Ethiopia_U_F)

"For me, the most effective extracurricular listening environment is the TV series. I learn how to make new words and sentences and how to pronounce them from the TV series." (Ethiopia_U_F)

"As we watch a TV series / film, we learn Turkish traditions, new words, accents." (Mozambique_U_M)

"While watching movies we understand in which case can we use expressions. In the movies, when the son comes $t_{0}$ home, we listen to their conversations. With time we are able to talk." (India_U_M)

"While watching movies, I learn both Turkish and Turkish culture." (China_CSF_M)

"I watch cartoons, they have simple words." (Lebanon_M_M)

"I love sports. I watch games outside, but I don't watch TV series or movies even if I know it are very useful because they speak very fast in them." (Ghana_DR_M) 
"Only men watch funny TV series. In our culture only women watch TV series. That's why we don't like TV series." (Nepal_DR_M)

"I love politics, so I watch the news. I listen to classical songs on TRT just for pronunciation." (Tanzania_DR_M)

"I watched a documentary about Atatürk because I was curious about his life." (Iran_DR_M)

"I love listening to songs and hymns." (Ghana_DR_M)

"I listened to the old songs because they are slow" (Afghanistan_M_F)

"I sing songs. I listen to the lyrics of on the Internet. I'm learning new words. I do it every day. No day without music." (Montenegro_U_F)

"I listen to songs on the Internet, I look at their lyrics. This way I learn new words, I memorize them. Over time it sticks in mind." (Latvia_M_F)

"I hate studying. I don't study at home. I travel a lot, with my Turkish friends. We talk while we're walking. I learned a lot of words. I don't watch movies and TV series. I don't like virtual life. For me it's a waste of time.” (Tunisia_M_M)

"People on the streets are more important to me. I listened to people on the streets, on the tram." (Mongolia_M_M)

"I listened to old people talking. Everyone loves different things, I want slow, more emotional speech.” (Thailand_U_M)

"It's more effective to listen to my roommates than to learn words using a dictionary." (Afghanistan_U_F)

"I watched Turkish videos for A1-A2 on Youtube." (Ethiopia_U_F)

"There is a book, both text and audio that I read and listen to. Very good for improving pronunciation." (Iraq_DR_M)

"I listen less. I don't watch television, I don't listen to songs." (Croatia_CSF_F)

When the thoughts of Turkish learners as a foreign language about their out of class listening skills are examined, it is seen that their out of class learning and experiences do not change according to a certain geographical area. Besides, it can be said that they experience different environments and experiences according to their individual features. Some learners enjoy listening to songs, while others do not. Similarly, in some cultures, watching TV series is not preferred by men because it is a behavior specific to women, while some learners have stated 
that they have learned new words and phrases especially from TV series. Some learners prefer to talk to slow-speaking elderly people, while some learners have little experience of listening.

\section{Findings about out of class speaking environments and experiences of Turkish language learners}

The learning environments and experiences used by the learners to improve their speaking skills while learning Turkish as a foreign language and their distribution according to geographical variables are given below (Table 3).

Table 3

Out of Class Speaking Environment-Experiences and Distribution by Geographical Variables

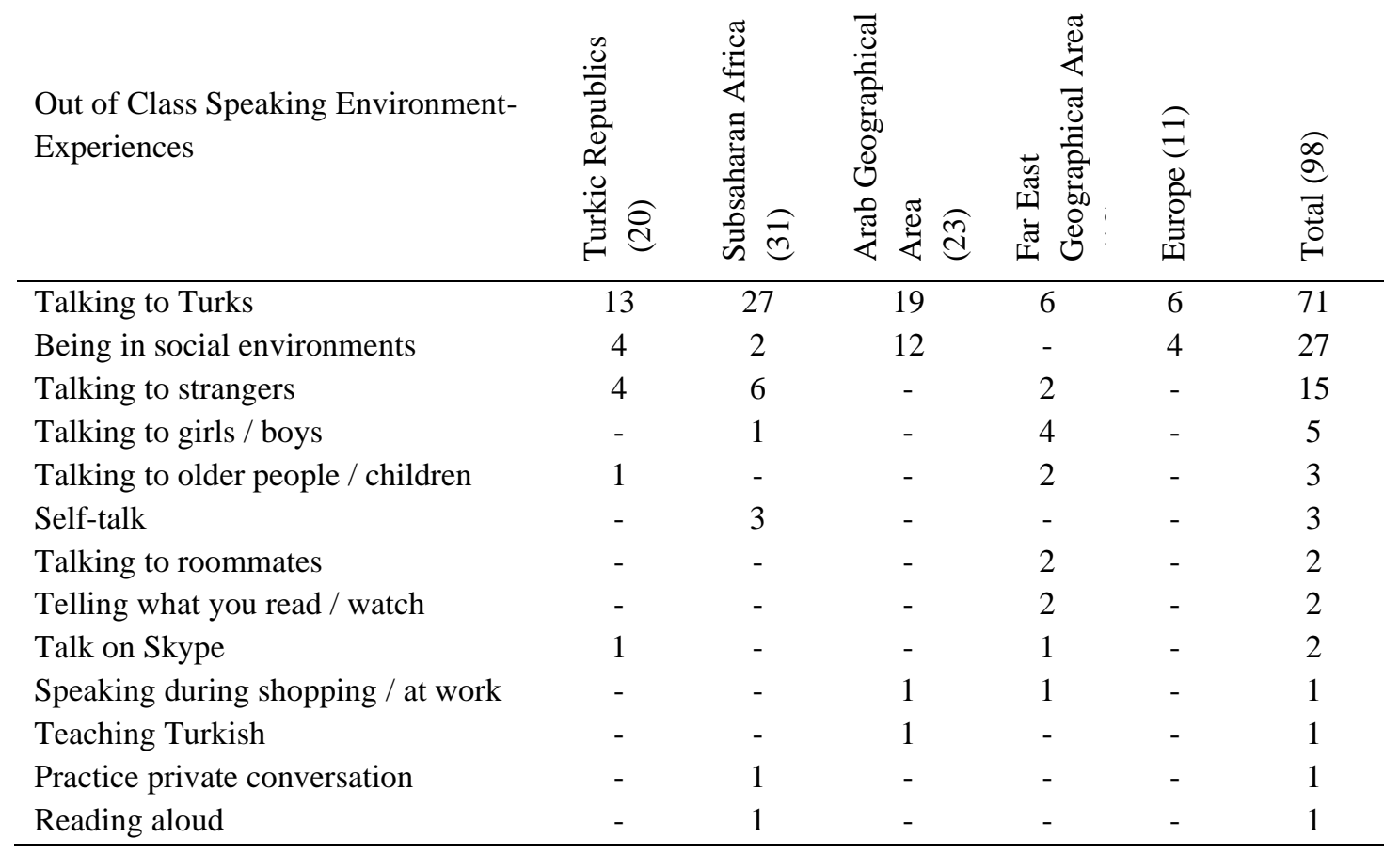

When Table 3 is examined, it is seen that those who learn Turkish as a foreign language experience 17 different speaking environments and experiences out of class. Among these, the most preferred ones are to talk to Turks, to be in social environments and to talk to foreigners. Besides, Far Eastern learners talk to the opposite sex and African learners prefer to speak to themselves. These preferences are noteworthy as out of class learning environments and experiences that are different among geographical groups. 
Some of the out of class speaking environments and experiences of learners who learn Turkish as a foreign language and come from Turkic Republics are cited below:

"I talk to the Turks a lot. My roommate was Turkish but my friend wouldn't speak. Then I went to the manager to change my room, I said my roommate does not speak at all." (Uzbekistan_U_M)

"My friends are talking, they use new words, I hear, I ask; what does this word mean?" (Afghanistan_U_M)

"The Turks correct me. I'm learning more from them. Foreigners speak like me." (Afghanistan_M_F)

"I changed my room because there were Afghans there. Now we speak Turkish. It would be too bad for me if I didn't change my room. I don't speak English to Turks because it could be dangerous for me, so I couldn't learn Turkish well." (Afghanistan_M_M)

"I changed my room. There were Afghans. Now we speak Turkish. It would be too bad for me if I didn't change my room. I don't speak English to Turks because it could be dangerous for me, so I couldn't learn Turkish well.”(Afghanistan_M_M)

It is known that the speaking skills of the learners from the Turkic Republics are better than the other groups because most of the words in Turkish are similar to the words in their own language. Most learners in this group wanted their roommates to be Turkish. They also have relatives or acquaintances in this group of learners in Turkey and they had experience of speaking Turkish with them.

Some of the out of class speaking environments and experiences of other learners who learn Turkish as a foreign language are cited below:

“We meet three Turkish friends and talk like teachers." (Tanzania_DR_M)

"It's better to talk to the Turks because it's their mother tongue. Foreign pronunciation is different. My pronunciation will be bad if I learn from strangers." (Yemen_DR_M)

"You must live with the Turks." (Tunusia_M_M)

"We need to find a girl who speaks Turkish. Turkish girls love to talk a lot, they ask a lot of questions." (Burkina Faso_M_M)

"I prefer talking to girls. I speak very little. Even in my own language, I am not so talkative.”(Mongolia_M_M) 
"I'm talking to the kids. They don't understand our mistakes. I prefer to talk to the Turks because they teach us. The girls are more appropriate.” (India_M_M)

"I speak Turkish during sports. Turks have correct pronunciation. Foreigners like me, but Turks like the ocean. Foreigners are like streams." (Algeria_M_M)

"I tried to make friends at the company. We speak both normal Turkish and business language. We can learn new words from the Turks." (Syria_M_M)

"I have two Turkish friends, my best friends. They helped improved my speech a lot. I spoke to the Turks in Turkish. Teaching Turkish to foreigners, speaking Turkish with Turks is more useful.” (Mauritania_U_M)

"It is more comfortable to speak Turkish with men." (Nepal_DR_M)

"Turkish with foreigners is better. I don't understand the Turks. But strangers speak slowly. Strangers are good for practice. You're not ashamed to make a mistake because they don't know. Foreigners to easily agree, but Turks to correct." (Ethiopia_U_F)

"Turkish is better learnt from foreigners. They speak slowly. They speak English." (Bangladesh DR_M)

"My roommates are strangers. We speak English, talk to Turks and girls. They talk about everything. "It's more instructive to talk for me." (Indonesia_M_M)

"I hate language since my childhood. I couldn't speak when I was a kid, so I wrote what I wanted.” (Thailand_U_M)

"I mostly talk to my roommates. They do not speak English at all. Some Turks do not speak English, so I speak only Turkish.” (Myanmar_U_M)

"I usually talk very little. I don't have many Turkish friends. That's why I read. Because I speak to myself while reading a book.” (Kosova_U_M)

"I have no social life. I just talk to my husband. He's not a chatty person. I talk to him. He doesn't correct my mistakes. I talk at the market." (Croatia_CSF_F)

When the thoughts of Turkish learners as a foreign language about the ability to speak out of class are considered; it can be said that out of class learning and experiences do not change according to geographical area and that they experience different environments and experiences according to their individual characteristics. It is seen that learners who are self-confident and do not have socialization problems experience speaking with Turks, the opposite sex and / or foreigners. Learners, who see themselves inadequate or incomplete in terms of these personality traits -depending on the situation- prefer to speak Turkish with their friends from the same 
country, husband/wife or self. Students who consider themselves inadequate in speaking skills have stated that they prefer writing.

\section{Findings about out of class reading environments and experiences of Turkish language learners}

The learning environments and experiences used by the learners to improve their reading skills while learning Turkish as a foreign language and their distribution according to geographical variables are given below (Table 4).

Table 4

Out of Class Reading Environment-Experiences and Distribution by Geographical Variables

\begin{tabular}{|c|c|c|c|c|c|c|}
\hline $\begin{array}{l}\text { Out of Class Reading Environment- } \\
\text { Experiences }\end{array}$ & 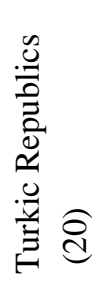 & 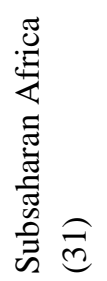 & 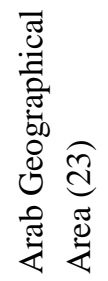 & 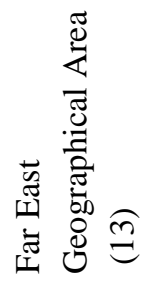 & $\begin{array}{l}\underset{\Xi}{\Xi} \\
\stackrel{0}{0} \\
\stackrel{\Xi}{\Xi}\end{array}$ & $\begin{array}{l}\stackrel{\infty}{\infty} \\
\substack{\pi \\
0}\end{array}$ \\
\hline Reading newspapers / magazines & 7 & 19 & 10 & 9 & 4 & 49 \\
\hline $\begin{array}{l}\text { Reading children books / fairy tales / } \\
\text { riddles }\end{array}$ & 10 & 18 & 9 & 2 & 4 & 41 \\
\hline Reading novels / stories / poems / lyrics & 9 & 6 & 10 & 6 & 2 & 33 \\
\hline $\begin{array}{l}\text { Reading books / newspapers / news / } \\
\text { cookbooks / grammar texts from the } \\
\text { Internet }\end{array}$ & 6 & 8 & 4 & 4 & 7 & 31 \\
\hline $\begin{array}{l}\text { Reading academic books / articles / } \\
\text { primary / secondary school books, } \\
\text { Turkish- English grammar books }\end{array}$ & 8 & 6 & 6 & 1 & - & 21 \\
\hline $\begin{array}{l}\text { Reading wrapping paper and } \\
\text { advertisements }\end{array}$ & 2 & 2 & 9 & 4 & 3 & 20 \\
\hline Reading on Facebook, Whatsapp, Twitter & 4 & 5 & 9 & - & 1 & 19 \\
\hline $\begin{array}{l}\text { Reading books about the academic } \\
\text { department }\end{array}$ & 2 & - & - & 3 & 2 & 10 \\
\hline $\begin{array}{l}\text { Reading subtitles of movies / TV series / } \\
\text { TED videos }\end{array}$ & - & - & 1 & 3 & - & 4 \\
\hline Reading book translations / religious books & - & 1 & 2 & 1 & - & 4 \\
\hline Reading SMSs / letters / dictionaries & - & 2 & - & 1 & - & 3 \\
\hline
\end{tabular}

When Table 4 is examined, it is seen that those who learn Turkish as a foreign language experience 34 different reading environments and experiences outside the course. The most preferred ones are "reading newspapers and magazines; reading children books, fairy tales, riddles; reading novels, stories, poetry, lyrics and reading books, newspapers, news, cookbooks, 
grammar texts from the Internet. In addition, the number of academic books, articles, primary / secondary school books, Turkish-English grammar book readings of students from Turkish Republics is also noteworthy. This learning environment and experience is most preferred by European learners for reading. Lastly, among the number of learners from the Arab geographical area, wrapping paper and advertisement readings and readings from Facebook, Whatsapp, and Twitter is higher than among the learners from other geographical regions.

Some of the out of class reading environments and experiences of other learners who learn Turkish as a foreign language are cited below:

"I'm reading a lot of books now so that I won't have problems next year." (Afghanistan_U_M)

"I watched the TV series Çalıkuşu. Then I took the book and read it." (Afghanistan_M_F)

"I read newspapers, I read 10 books. I'm reading, there is everything if I read. When there is reading there is formal conversation; no reading, no official speech" (Tanzania_DR_M)

"I read the Bible in Turkish." (Ghana_M_M)

"I was reading children's books first, now I'm reading novels." (Tanzania_M_M)

"I read 5-6-7th grade course books. I downloaded them from meb.gov.tr. The most important thing for reading is textbooks because I learned English so. Because there are the most important words, the most useful, and the most used words in the course books." (India_M_M)

"In the beginning I read one page in Turkish and one page in French in A1 and A2. Now I understand $90 \%$ of the novels in terms of vocabulary." (Tunisia_M_F)

"There are many good books, one page in Turkish and one page in English. The sentences are the same. This is very good. When I didn't understand anything, I looked at the English page." (Latvia_M_F)

"Reading is too boring for me. I love reading advertisements. I read the package when buying biscuits or food. I bought a newspaper, I tried to read it, unfortunately it was impossible because it's boring." (Tunisia_M_M)

"I read what I understand. I read newspapers." (Nepal_DR_M)

"I'm reading a dictionary." (China_CSF_M)

"I read the news. I read Turkish newspapers." (Montenegro_M_M) 


\section{"I have Aljazeera Turk application on my phone, I read the news." (Afghanistan_M_F) \\ "I don't read Turkish at all because I'm scared." (Ukraine_CSF_F)}

When the thoughts of Turkish learners as a foreign language about their reading skills are examined; out of class learning and experiences show individual differences. The learners have experienced the learning environments and experiences that they used to learn a foreign language in the past while learning Turkish. It was also discussed that the reading environments and experiences out of class did not change according to geographical region. Students' attitudes towards reading seem to be effective. There are learners who understand the importance of reading, who stop reading because they cannot understand when using different reading environments and experiences, who prefer reading a dictionary in order to learn Turkish more quickly, and learners who do not read because they are bored or afraid of reading.

Findings about out of class writing environments and experiences of Turkish language learners

The learning environment and experiences used by the learners to improve their writing skills while learning Turkish as a foreign language and their distribution according to geographical variables are given below (Table 5).

Table 5

Out of Class Writing Environment-Experiences and Distribution by Geographical Variables

\begin{tabular}{|c|c|c|c|c|c|c|c|}
\hline $\begin{array}{l}\text { Out of Class Writing Environment- } \\
\text { Experiences }\end{array}$ & 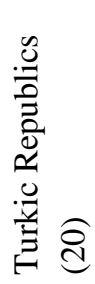 & 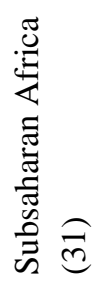 & 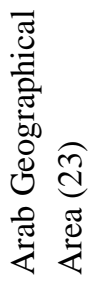 & 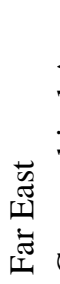 & 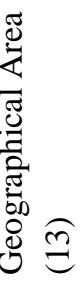 & 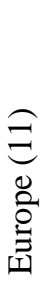 & 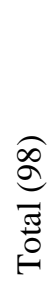 \\
\hline Writing on Facebook, Whatsapp & 5 & 42 & 25 & & 9 & 8 & 90 \\
\hline Write SMSs / mail & 2 & 20 & 10 & & 4 & 4 & 40 \\
\hline Rewrite text & 6 & 2 & 1 & & 1 & 2 & 13 \\
\hline Summarizing & 3 & 5 & 1 & & 1 & 2 & 12 \\
\hline Writing by translation & 4 & 3 & 1 & & 1 & 2 & 11 \\
\hline Writing on any topic & 3 & 3 & - & & 3 & 1 & 10 \\
\hline Keeping a diary/ writing a letter & - & 2 & 1 & & 3 & 2 & 8 \\
\hline Writing stories / poetry / lyrics & - & 2 & 2 & & 2 & - & 5 \\
\hline Taking notes & 1 & 1 & 2 & & - & - & 4 \\
\hline
\end{tabular}




\begin{tabular}{|c|c|c|c|c|c|c|}
\hline $\begin{array}{l}\text { Out of Class Writing Environment- } \\
\text { Experiences }\end{array}$ & 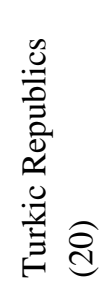 & 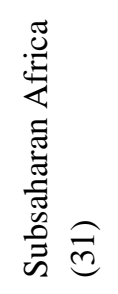 & 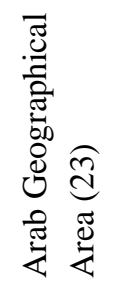 & 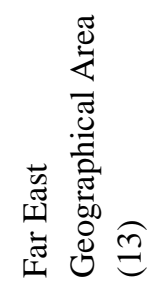 & 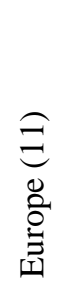 & 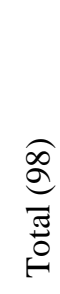 \\
\hline $\begin{array}{l}\text { Keeping a vocabulary notebook/ } \\
\text { Writing word cards }\end{array}$ & 3 & - & - & 1 & - & 4 \\
\hline Writing lyrics while listening to songs & 1 & - & 1 & - & - & 3 \\
\hline $\begin{array}{l}\text { Solving tests on the Internet / writing } \\
\text { on the site }\end{array}$ & 1 & 1 & - & - & - & 2 \\
\hline $\begin{array}{l}\text { Writing sentences while watching TV } \\
\text { series }\end{array}$ & 1 & - & - & - & - & 1 \\
\hline Doing Crossword Puzzles & 1 & - & - & - & - & 1 \\
\hline
\end{tabular}

When Table 5 is examined, it is seen that those who learn Turkish as a foreign language experience 21 different writing environments and experiences. The most preferred ones are "writing on social media such as Facebook, Whatsapp, writing SMS and mail, and rewriting a text." In addition, it is noteworthy that learners from the Turkic Republics use a slightly different writing environment and experiences, but unlike learners from other geographical regions, they prefer writing on social media. Likewise, learners from Africa have experienced more out of class environments and experiences to write. Finally, it is noteworthy that learners from Europe prefer only 10 out of a total of 21 out of class writing environments and experiences.

Some of the out of class writing environments and experiences of other learners who learn Turkish as a foreign language are cited below:

"Writing is my favorite thing because writing is easier than speaking. I have more time to think about my ideas. I use my phone in Turkish. I write on Whatsapp in Turkish. If there's a mistake, I don't do it again. I write message in Turkish." (Syria_CSF_M)

“I make comments on Facebook. I pay attention to grammar.” (Ethiopia_U_F)

"I write sentences in songs and TV series. That's why I'm good at writing." (Afghanistan_M_F)

“After watching the TV series, I write its summary.”(Mozambique_M_M)

"I write an article summary in Persian. I translate it into Turkish. I rewrite the Turkish text.” (Afghanistan_M_M) 
"I write letters, messages and abstracts; my friend corrects my mistakes. It's very useful. I have written poetry several times." (Indonesia_M_F)

"I learn new words and write sentences with them. My roommate checks them." (Lebanon_M_M)

"I choose a topic and write about it. My husband checks it." (Croatia_CSF_F)

"Since I did little speaking practice, I make up for it by writing." (Albania_M_F)

"I don't have a habit of writing. I just choose words from the dictionary. I make sentences using that word." (Myanmar_U_M)

"If I make a mistake, I won't know how to correct it. That's why I need help." (Montenegro

_U_F)

"I write a lot in Arabic, but Turkish is not obligatory, so I do not. There is not much control.”(Iraq_DR_M)

"I'm just lazy. I don't want to write. I only write short messages?" (Mauritania_DR_M)

"I don't like writing at all. I'm depressed about writing. I don't write anything for ten minutes during the exam. Simple sentences seem to me childish. That's why I quit because I don't like it. I don't struggle. I think I may have been influenced by my childhood. My teacher always said "Do not always use the same word in another sentence." This impressed me. We need to find a synonym. That's how they taught us." (Uzbekistan_U_F)

When the thoughts of Turkish learners as a foreign language about their writing skills are examined; it is seen that out of class writing environments and experiences show individual differences as in the reading skills. There are learners who like and practice writing skills as well as learners who do not prefer writing because they are bored by it. It is seen that the students who have good writing skills in their mother tongue have good writing skills in the foreign language and they also use the experiences they used in learning other foreign languages while learning Turkish. There are learners who receive support from Turks, friends from their countries, roommates and relatives in writing. The students who think that they cannot write because they think that they do not know Turkish grammar well and don't write because they are not checked are also noteworthy. The most striking situation is the Uzbekistanian learner who is educated by the Russian education system. The Uzbek learner, who did not want to write simple sentences, developed prejudice against writing Turkish. 
When the data related to the language learning environment and experiences used by the learners of Turkish as a foreign language are examined, it can be found that individual differences are prominent in each language skill in general. When choosing a language learning environment and experience out of class, learners benefit from previous foreign language learning experiences, personality traits (such as self-esteem, courage, socialization) are influential in this choice, they face cultural differences, find their own learning experiences (such as talking to older people) and form their friendships accordingly. Also knowing their mother tongue well (a good knowledge of mother tongue), the presence of relatives or acquaintances in Turkey, the contribution of language skills to the study areas, prejudices against reading and writing affect the out of class language learning environment and experiences.

When the data on the features of out of class language learning environments and experiences are examined according to geographical area, there are two important findings. The first one is the effect of the mother tongue and Turkish being from the same language family on the speaking environments and experiences of the learners coming from the Turkic Republics. The second one is the Uzbekistanian learner developing prejudice against Turkish writing.

\section{Discussion}

In this section, the findings obtained in the research are discussed in terms of the out of class language learning environments and experiences used by the learners of Turkish as a foreign language. The main discussion area of the research is the change in the language learning environment and experiences of the learners of Turkish as a foreign language according to individual differences. The fact that learners frequently use past learning environments and experiences, and even benefit from the environments and experiences used by other friends, reveals the importance of cooperation and communication in foreign language teaching. When the effect of communication on learning a foreign language is mentioned, it is necessary to take into consideration the effects of personality traits and cultural differences. For learners, who are not self-confident, have poor interpersonal relationships and are not brave, learning environments should be organized in different ways. In addition, the learning experiences that learners find in their own way, such as talking to older people and children, show that places 
such as the streets and shopping places should be taken into consideration when organizing learning environments. According to the research findings, other issues to be considered while organizing learning environments are: individuals' knowledge of their mother tongue, whether they have relatives or acquaintances in the geographical area where they learn the language, and whether they have prejudices against any of the four language skills.

When arranging the out of class language learning environments according to geographical area, it is necessary to use the relationship between the native languages of Turkic learners and Turkish. According to the findings, it is seen that concrete ties to be established between these languages including Turkish dialects and Turkish will have a positive effect on their speaking skills. By the way, while organizing the learning environments knowing the importance given to one or more of the four language skills in the educational systems of the geographical regions where the learners come from can guide the learners and teachers.

According to the findings of the research, besides the guidance of students' and their peers' out of class listening environments and experiences, the presence of relatives living in Turkey is seen to be effective. This finding shows that while arranging out of class learning environments, arrangements should be made by taking the learner's environment into consideration. Considering that the students prefer listening to Turks in places such as streets, buses and dormitories as out of class listening activities, it is an expected behavior for students who have no friends, to listen in their mother tongue and to be reluctant to learn Turkish. The experience of 23 different listening environments and experiences such as "watching TV series, watching movies, listening to songs and listening to Turkish speaking" coincides with the findings of Chusanachati (2009). However, when deciding to use some environments and experiences such as watching TV series and movies as out of class learning environments and experiences, cultural differences should be considered. As a matter of fact, the research findings showed that watching TV series in Nepal is not preferred by men because it is a behavior specific to women. Likewise, African students' watching football matches is related to their sports ability as well as their football culture. Therefore, the change in the listening environment and experiences chosen by the learners to develop their Turkish according to their interests and individual differences is similar to the findings in Knight's (2007) master thesis.

Among the 17 different speaking environments and experiences used by the learners of Turkish as a foreign language, the presence of speaking with Turks, being in social environments and 
speaking with foreigners is different from Chusanachati's (2009) finding that English learners in Thailand do not speak too much out of class. This is because English-speaking environments in Thailand are limited, whereas students who participated in the research are learning Turkish in Turkey. In this respect, it seems that Knight's (2007) finding that the conversations of the learners with the natural speakers would improve the language proficiency. A wide range of variability between learners talking to the opposite sex and talking to themselves show the effect of personality traits such as self-esteem, courage and socialization. Students who are selfconfident and do not have socialization problems, experience speaking with Turks, the opposite sex and / or foreigners; learners who consider themselves inadequate or incomplete in terms of these personality traits -depending on the situation- prefer to speak with friends from their own country, husband/wife or oneself. Those who will learn and teach Turkish as a foreign language should take into consideration the attempt to compensate for the inability of speaking skills with writing skills as well as personality traits when arranging out of class learning environments.

Among the 34 out of class reading environments and experiences of those who learn Turkish as a foreign language, they prefer "reading newspapers, magazines, children books, novels, stories, poetry, lyrics and reading from the Internet. This requires individual differences to be taken into consideration when organizing out of class learning environments. When organizing out of class reading environments, students' attitudes towards reading should also be considered. While some learners understand the importance of reading, some learners may give up and fear reading because they do not understand, and others may get bored from reading because of their personality.

Among the 21 different writing environments and experiences used by the learners of Turkish as a foreign language, writing in different social media environments necessitates creating a close connection between writing and technology for those who will learn and teach Turkish as a foreign language.

The findings of the research show that in this era when the Internet and technology have entered our lives so rapidly, the use of technology in the classroom and out of class learning environments shows that young people will actively participate in the writing experience. The fact that the learners from the Turkic Republics prefer face-to-face interaction instead of using social media may be because their Turkish language skills are better than those of the other groups. The fact that learners from Europe prefer only 10 out of a total of 21 out of class writing 
environments and experiences may be due to the fact that they have more writing environments and experiences in their native language than learners from other geographical regions. The research findings show that there will be foreign learners who like writing in Turkish as well as learners who are bored of writing and prefer not to write. Based on the expression of the Uzbek learner, knowing the learning environment and experiences of the learners while learning their mother tongue makes it easier to provide them with an appropriate out of class writing learning environment and experience. It was seen that the students in the study group were afraid to write due to the fact that both the mother tongue of the learners in the study group and the other foreign languages they learned were generally dependent on the Indo-European and HamitoSemitic languages. This led to the prejudice that Turkish was difficult in grammar. The fact that the departmental courses to be studied by the learners at the end of the Turkish education are in English is an important factor in their neglect of writing skills. In the interviews, the learners stated that they did not repeat the mistakes when their writing was checked. Again, in the same interview, Learning Turkish in Turkey was more effective in developing listening and speaking skills but it was said that it was not very effective in helping improve the reading and writing skills. Learners do not make special efforts for listening and speaking skills because they are in a natural environment and because reading and writing require special efforts, only those with interest and ability have experienced these two skills.

\section{Conclusion}

In this study in which out of class language learning environments and experiences of Turkish language learners are investigated, the results are presented in line with the sub-problems of the research.

From the findings, it is possible to reach the following conclusions on the learning environments and experiences used by learners of Turkish as a foreign language:

- The learning environment and experiences used by learners of Turkish as a foreign language out of class vary according to their characteristics.

- The learning environment and experiences used by learners of Turkish as a foreign language out of class generally do not vary according to geographical region.

- The learning environments and experiences used in learning other foreign languages are also used when learning Turkish. 
- Those who learn Turkish as a foreign language prefer watching TV series, movies, listening to songs and talking to Turks.

- Environmental features, cultural features and interests (academic education area, work area, social area) and social features are effective in determining the preferences of out of class listening environments and experiences.

- Those who learn Turkish as a foreign language prefer to speak to Turks, to be in social environments and to speak to foreigners as the out of class environment and experience.

- Personality (self-confident, courageous, social, vs. introverted, etc.) of the learners of Turkish as a foreign language is effective in determining out of class speaking environment and experience preferences.

- In out of class speaking environment and experience, learners, whose mother tongues belong to the same dialect as Turkish, make different choices compared with the students coming from other geographical regions.

- Foreign learners, who think that the out of class speaking experience is insufficient, prefer to compensate for this deficiency by increasing their writing experiences.

- Those who learn Turkish as a foreign language prefer "reading newspapers, magazines, children's books, novels, stories, poetry, lyrics, and reading books from the Internet as their out of class reading environments and experiences.

- In the out of class reading environments to be organized for the learners of Turkish as a foreign language, taking into consideration their own cultures and religions and similarities with the Turkish culture affects the reading experiences positively.

- The positive awareness of the importance of reading affects the reading environment and experiences of those who learn Turkish as a foreign language.

- Those who learn Turkish as a foreign language prefer writing mostly on social media and technological environments as an out of class writing environment and experience.

- Learners from Europe use fewer Turkish writing environments and experiences because they can find more writing environments and experiences in their native languages.

- The attitude towards writing while learning Turkish as a foreign language affects the preferences of the out of class writing environment and experience.

- Students who are competent in writing in their mother tongue are also successful in out of class writing environments and experiences while learning Turkish. 
- The mother tongue of the learners of Turkish as a foreign language and the language family to which the foreign languages they are familiar with belong, affect the out of class writing environment and experiences in Turkish.

- The importance given to the different language skills in the native education systems of those who learn Turkish as a foreign language in the geographical areas they come from affects their out of class learning environments and experiences while learning Turkish as a foreign language.

\section{Recommendations}

Based on the results of the out of class learning environments used by the learners of Turkish as a foreign language, the following suggestions can be developed:

- Due to the fact that those who learn Turkish as a foreign language experience extracurricular language learning environments according to individual differences, for the institutions and people who will arrange extracurricular learning environments for these learners; education, seminars and certificates should be provided for service such as mother tongue acquisition processes, foreign language teaching, education systems of countries where foreign students live, features of their mother tongue, geographical and cultural differences, and psychology in language learning process.

- Portal and Internet sites with systematic and progressive course videos encompassing the four basic language skills and grammar subjects should be produced and learners should be able to experience such environments out of class.

- In the teaching of Turkish as a foreign language, the different geographical regions should be described by scientific studies and different learning environments and experiences should be organized according to each geographical region.

- The learners should be encouraged to stay in dormitories and hostels in order to ensure that they stay together with the native speakers during the process of preparing for (learning) the Turkish language.

- In order to learn the Turkish culture, words and expressions, learners generally prefer watching television TV series and movies. Students should be guided in their choice of movies and television TV series, songs, books, magazines, newspapers. 
- In order for the learners to develop their writing skills, their writings must be checked by both the teacher and their peers.

- Learners who have departmental courses in English or who will write their theses/ dissertations in English are more reluctant to write and read in Turkish. Universities and The Council of Higher Education (YÖK) should take the necessary precautions to make students write their dissertations and assignments in Turkish.

- Based on the result that learners experience different extracurricular learning environments, individual differences should be taken into consideration when organizing extracurricular learning environments.

- Based on the conclusion that the students prefer to write in technological environments, it is recommended that those who teach Turkish as a foreign language use technological materials in out of class writing environments.

- Based on the conclusion that the students prefer to listen to songs out of class, Turkish music environments should be arranged for the learners of Turkish as a foreign language and the students should be included in these environments.

- Social media should be used more actively in the centers where Turkish is taught as a foreign language and by teachers working there.

- From level B2 and above, international learners should be directed to the departments where they will study, to the environments they will work and live in order to increase and diversify their out of class language learning environments and experiences.

- Social activities such as symposiums, conferences, seminars, picnics, shopping should be planned and students should participate in these activities.

- Applications such as e-books, dictionaries, games and vocabulary teaching that can be used on smart phones should be developed in order to increase the students' out of class listening, speaking, reading and writing environments and experiences.

- Out of class language learning environments and experiences should be taken into consideration during the curriculum studies and assessment and evaluation stages of teaching Turkish as a foreign language. 


\section{References}

Barın, E. (2004). Yabancılara türkçe öğretiminde ilkeler. Hacettepe Üniversitesi Türkiyat Araştırmaları, 1, 19-30.

Bayraktar, N. (2003). Yabancılara türkçe öğretiminin tarihsel gelişimi. Ankara Üniversitesi TÖMER, 119, 58-71.

Bozorgian, H. (2012). The relationship between listening and other language skills in international english language testing system. Theory and Practice in Language Studies, 2(4), 657-663.

Büyükikiz, K. (2014). Yabancılara türkçe öğretimi alanında hazırlanan lisansüstü tezler üzerine bir inceleme. Mustafa Kemal Üniversitesi Sosyal Bilimler Enstitüsü Dergisi, 11(25), 203 213.

Chusanachoti, R. (2009). Efl learning through language activities outside the classroom: a case study of English education students in Thailand. (Yayınlanmamış doktora tezi). Michigan State University, Michigan.

Creswell, J. (2013). Araştırma deseni nitel, nicel ve karma yöntem yaklaşımları. (Selçuk Beşir Demir, Çev. Ed.) Eğiten Kitap: Ankara.

DergiPark (2019). Arama Sonuçları: Ders dışı öğrenme ortamları. https://dergipark.org.tr/tr/search?q=ders+d\%C4\%B1\%C5\%9F\%C4\%B1+\%C3\%B6\%C 4\%9Frenme+ortamlar\%C4\%B1\&section=articles. Retrieved December 13, 2019, from https://dergipark.org.tr/tr/search?q=ders+d\%C4\%B1\%C5\%9F\%C4\%B1+\%C3\%B6\%C 4\%9Frenme+ortamlar\%C4\%B1\&section=articles.

Er, O., Biçer, N., \& Bozkırlı, K. (2012). Yabancılara türkçe öğretiminde karşılaşılan sorunların ilgili alan yazını ışığında değerlendirilmesi. Uluslararası Türkçe Edebiyat Kültür Eğitim Dergisi, 1(2), 51-69.

Karababa, Z. (2009). Yabancı dil olarak türkçenin öğretimi ve karşılaşılan sorunlar. Ankara Üniversitesi Eğitim Bilimleri Fakültesi Dergisi, 42(2), 265-278.

Knight, L.T. (2007). Beyond the classroom walls: a study of out of class English use by adult communıty college ESL students (Yayınlanmamış yüksek lisans tezi). Portland State University, Portland, Oregon. 
Lundsteen, S. (1971). Listening: its impact on reading and the other language arts. Urbana ILL: National Council of Teachers of English.

Nan, C. (2018). Implications of interrelationship among four language skills for high school english teaching. Journal of Language Teaching and Research, 9(2), 418-423,

Yıldırım, A., \& Şimşek, H. (2013). Sosyal bilimlerde nitel araştırma yöntemleri. Ankara: Seçkin Yayınları.

YOK (2019). Arama sonuçlart: Türkçe öğretimi. Retrieved December 13, 2019, from https://tez.yok.gov.tr/UlusalTezMerkezi/tezSorguSonucYeni.jsp. 